\title{
Correction to: Migalastat: A Review in Fabry Disease
}

\author{
Emma H. McCafferty ${ }^{1}$. Lesley J. Scott ${ }^{1}$
}

Published online: 10 July 2019

(c) Springer Nature 2019

\section{Correction to: Drugs (2019) 79:543-554 https://doi.org/10.1007/s40265-019-01090-4}

The article Migalastat: A Review in Fabry Disease, written by Emma H. McCafferty, Lesley J. Scott, was originally published Online First without open access. After publication in volume 79, issue 5, pages 543-554 Amicus Therapeutics, Inc., requested that the article be Open Choice to make the article an open access publication. Post-publication open access was funded by Amicus Therapeutics, Inc. The article is forthwith distributed under the terms of the Creative Commons Attribution-NonCommercial 4.0 International License (http://creativecommons.org/licenses/by-nc/4.0/), which permits any noncommercial use, duplication, adaptation, distribution and reproduction in any medium or format, as long as you give appropriate credit to the original author(s) and the source, provide a link to the Creative Commons license and indicate if changes were made.

The original article has been corrected.

Open Access This article is distributed under the terms of the Creative Commons Attribution-NonCommercial 4.0 International License (http://creativecommons.org/licenses/by-nc/4.0/), which permits any noncommercial use, distribution, and reproduction in any medium, provided you give appropriate credit to the original author(s) and the source, provide a link to the Creative Commons license, and indicate if changes were made. 